\title{
Understanding Floral Induction and Morphogenesis
}

\author{
held at the \\ Sacramento Convention Center \\ Sacramento, California \\ 22 July 2001
}

\begin{abstract}
sponsored by the
Crop Physiology, Citrus Crops, Pomology, and

Plant Biotechnology Working Groups of the American Society for Horticultural Science
\end{abstract}

published by the American Society for Horticultural Science

Alexandria, VA 22314-2851

as a special insert in HortScience 38(7), December 2003 


\section{Colloquium Papers and Authors}

\section{Presiding: Douglas D. Archbold}

Understanding Floral Induction and Morphogenesis: An Introduction to the Colloquium Douglas D. Archbold

Molecular Mechanism of Shoot Determinacy and Flowering in Arabidopsis

Z.R. Sung, L.-J. Chen, Y.-H. Moon, and N. Yoshida

Diversification of Floral Homeotic Gene Function

Vivian F. Irish

Management of Flowering in Three Tropical and Subtropical Fruit Tree Species

Thomas L. Davenport 